\title{
PERLINDUNGAN HUKUM KERJASAMA PT. SARANA JATENG VENTURA DENGAN PERUSAHAAN PASANGAN USAHA DALAM PEMBERIAN MODAL VENTURA
}

\author{
Edy Nurcahyo \\ Program Studi Ilmu Hukum, Fakultas Hukum \\ Universitas Muhammadiyah Buton, \\ Email: cahyonur3dy@gmail.com
}

\begin{abstract}
ABSTRAK
Tujuan dari penelitian hukum ini adalah untuk mendeskripsikan pola-pola hubungan hukum penyaluran modal ventura yang terjadi antara Perusahaan Modal Ventura dengan Perusahaan Pasangan Usaha dan untuk mendeskripsikan perlindungan hukum terhadap perusahaan modal ventura dan perusahaan pasangan usaha dalam kerjasama modal ventura yang disalurkan oleh PT. Sarana Jateng Ventura. Metode penelitian ini menggunakan pendekatan doktrinal, penulis memilih bentuk pendekatan normatif yang berupa inventarisasi peraturan perundang-undangan dan penemuan hukum in-concreto.

Hasil penelitian peneliti menunjukkan bahwa pola hubungan hukum yang terjadi antara PT. Sarana Jateng Ventura dengan Perusahaan Pasangan Usahanya, bila dipandang dari sudut klausul perjanjian telah terkonstruksi sebagai perjanjian modal ventura sebagaimana diatur dalam Peraturan Menteri Keuangan Nomor 18/PMK.010/2012 tentang Perusahaan Modal Ventura yaitu pola hubungan hukum dengan Pola Bagi Hasil. Perlindungan hukum terhadap PT. Sarana Jateng Ventura dan Perusahaan Pasangan Usaha selaku subyek hukum telah mendapat perlindungan hukum baik dari segi hukum privat maupun hukum publik.
\end{abstract}

\section{ABSTRACT}

The purpose of this legal research is to describe the patterns of distribution of venture capital legal relationship that occurs between the Venture Capital Partnership Company and to describe the legal protection of the venture capital and joint-venture company in cooperation venture capital channeled by PT. Sarana Jateng Ventura. This research method using doctrinal approach, the author chose the shape of the normative approach in the form of an inventory of legislation and legal discovery in-concreto.

The results of the study the researchers showed that the pattern of legal relationships that occur between PT. Sarana Jateng Ventura with her business partner Company, in light of the treaty clause has been constructed as a venture capital agreement as set out in Finance Minister Regulation No. 18 / PMK.010 / 2012 on the Venture Capital Company is a pattern of legal relationship with the Revenue-Sharing. Legal protection of the PT. Sarana Jateng Ventura and Partnership Company as a legal subject has received legal protection in terms of both private law and public law.

Keywords: Legal Protection, Cooperation, Venture Capital. 


\section{PENDAHULUAN}

Menurut Peraturan Menteri

Keuangan No.18/PMK.010/2012 tentang

Perusahaan Modal Ventura Pasal 11 ayat (1) bahwa:

"PMV didirikan dalam bentuk badan hukum: a. Perseroan Terbatas; atau b. Koperasi."

Perusahaan modal ventura yang menurut paraturan harus berbentuk PT atau koperasi, tetapi perusahaan pasangan usaha tidak disyaratkan demikian. Dalam Peraturan Menteri keuangan No. 18/PMK.010/2012 tentang Perusahaan Modal Ventura, Pasal 1 angka (3) perusahaan pasangan usaha harus berbentuk Perusahaan atau Usaha Mikro, Kecil, dan Menengah. Kata "perusahaan" cakupannya sangat luas, dapat berupa perusahaan berbadan hukum atau yang tidak berbadan hukum.Jadi perusahaan pasangan usaha bisa saja dalam bentuk PT, Koperasi, CV, Firma, bahkan perusahaan perorangan atau usaha dagang. ${ }^{1}$

Adanya perbedaan bentuk badan usaha pada PPU akan berpengaruh pada pola hubungan hukum antara Perusahaan Modal Ventura dengan Perusahaan

1 Hasanuddin Rahman, Segi-segi Hukum \& Manajemen Modal Ventura, Bandung: PT. Citra Aditya Bakti, 2003, hal. 27
Pasangan Usaha, karena masing-masing dari PPU memiliki karakteristik yang berbeda, yang menjadi masalah adalah ketika hubungan hukum antara keduanya menjadikan Perusahaan Modal Ventura tidak sesuai dengan asumsi teoretis bahwa Perusahaan Modal Ventura merupakan partner dari pasangan usaha.

Sementara dalam KUHPerdata, mengacu pada Pasal 1618 dan 1619 ayat (2) KUHPer, persekutuan perdata yang dikenal dengan nama matschaap berarti perjanjian antara dua orang atau lebih mengikatkan diri untuk memasukan sesuatu (inbreng) ke dalam persekutuan, dengan maksud membagi keuntungan. Inbreng itu bisa berupa uang, barang ataupun keahlian. ${ }^{2}$ Telah ketahui bahwa di antara badan-badan usaha yang lazim dipergunakan oleh masyarakat usahawan saat ini (terutama yang menjadi perusahaan pasangan usaha) memiliki perbedaan instrumen modalnya.Seperti saham untuk PT, sero untuk CV dan firma, dan simpanan (pokok dan wajib) untuk koperasi. Inbreng tersebut akan berpengaruh pada pola hubungan hukum. Modal Ventura seharusnya terkontruksi sebagai lembaga penyertaan modal, sebagaimana sekutu dalam

\footnotetext{
${ }^{2}$ http://www.aspek hukum dalam bisnis.com, tanggal 1 Februari 2014
} 
persekutuan Firma, persekutuan

Komanditer, atau pemegang saham pada perseroan terbatas. Apakah konstruksi hubungan hukum yang demikian terjadi di PT. Sarana Jateng Ventura?,

Syarat-syarat yang Top of For lazim diperjanjikan dalam kontrak pemberian modal ventura, antara lain adalah $:^{3}$

1. Suku bunga atau besarnya persentase bagi hasil dari modal ventura yang diberikan;

2. Jangka waktu penggunaan modal ventura oleh perusahaan pasangan usaha.

3. Cara-cara pengembalian modal ventura dari perusahaan pasangan usaha kepada perusahaan modal ventura.

4. Jaminan atau agunan atas pemberian modal ventura tersebut.

5. Biaya yang harus dikeluarkan dan menjadi tanggungan perusahaan pasangan usaha.

6. Bantuan manajemen atau keikutsertaan pihak perusahaan modal ventura ke dalam manajemen/operasional perusahaan pasangan usaha.

Seluruh syarat tersebut di atas dimasukkan ke dalam pasal-pasal

${ }^{3}$ Hasanuddin Rahman, segi-segi \& Manajemen Modal Ventura,Bandung:PT. Citra Aditya Bakti, 2003, hlm.119. kontrak/perjanjian pemberian modal ventura.

Perjanjian yang dibuat oleh kedua belah pihak harus dapat melindungi kepentingan PMV dan PPU secara berimbang meski posisi PMV sebagai pihak yang menyediakan fasilitas modal dan tenaga ahli, yang berhadapan dengan PPU sebagai pihak yang membutuhkan fasilitas modal pembiayaan dan tenaga ahli.

Berdasasrkan hal yang telah diuraikan diatas, maka untuk dapat mengetahui pola hubungan hukum antara PT. Sarana Jateng Ventura dengan Perusahaan Pasangan Usaha (PPU) serta perlindungan dalam pemberian modal ventura maka peneliti mengambil judul dalam penelitian hukum ini, adalah: " perlindungan hukum kerjasama PT. Sarana Jateng Ventura dengan Perusahaan Pasangan Usaha dalam pemberian modal ventura"

Adapun rumusan masalah dari problematika tersebut, yakni; (1) Bagaimana pola-pola hubungan hukum penyaluran modal ventura yang terjadi antara PT. Sarana Jateng Ventura dengan Perusahaan Pasangan Usahanya?, (2) Bagaimana perlindungan hukum terhadap Perusahaan Modal Ventura dan Perusahaan Pasangan 
Usaha dalam kerja sama modal ventura yang disalurkan oleh PT. Sarana Jateng Ventura?

\section{METODE PENELITIAN}

Penelitian ini mendasarkan pada penelitian hukum yang dilakukan dengan pendekatan doktrinal ${ }^{4}$, karena dalam penelitian ini hukum dikonsepkan, sebagai norma-norma tertulis yang dibuat dan diundangkan oleh lembaga atau oleh pejabat Negara yang berwenang. Hukum dipandang sebagai suatu lembaga yang otonom, terlepas dari lembaga-lembaga lainnya yang ada di masyarakat. Oleh karena itu pengkajian yang dilakukan, hanyalah "terbatas" pada data sekunder (dokumendokumen hukum) yang terkait dengan obyek yang diteliti.

Dari berbagai jenis metode pendekatan yuridis normatif $^{5}$ yang dikenal, peneliti memilih bentuk pendekatan normatif yang berupa, inventarisasi peraturan perundangundangan dan penemuan hukum inconcreto.

${ }^{4}$ http://www.artikelkomplit.com/2012/07 /metode-penelitian hukum.html diambil tanggal 12 Maret 2014, pukul 19:42,

${ }^{5}$ Ronny Hanitijo Soemitro, Metode Penelitian Hukum dan jurimetri, Ghalia Indonesia, Jakarta, 1988, hlm. 11

\section{PEMBAHASAN}

\section{Pola Hubungan Hukum}

Dalam Pasal 2 Peraturan Menteri Keuangan Nomor 18 /PMK.010/2012 Tentang Perusahaan Modal Ventura, Kegiatan Usaha Perusahaan Modal Ventura Meliputi:

a. Penyertaan saham (equity participation);

b. Penyertaan melalui pembelian obligasi konversi (quasi equityparticipation); dan/atau

c. Pembiayaan berdasarkan pembagian atas hasil usaha (profit/revenue sharing)

Isi dari perjanjian modal ventura tergantung dari jenis kegiatan usaha yang disepakati para pihak. Ketiga bentuk kegiatan usaha modal ventura sebagaimana telah ditentukan dalam Pasal 2 Peraturan Menteri Keuangan Nomor 18/PMK.010/2012 tersebut akan menjadi pola hubungan hukum yang dapat dipilih salah satu pola-nya dalam merealisasikan pembiayaan modal ventura. Ketiga pola hubungan hukum tersebut dapat diuraikan sebagai berikut:

\section{a. Penyertaan Saham (equity participation)}

Penyertaan saham wajib dilakukan oleh PMV dalam bentuk penyertaan modal secara langsung kepada PPU yang berbentuk 
badan hukum perseroan terbatas untuk jangka waktu tertentu sebagaiaman dimaksud dalam peraturan menteri ini ${ }^{6}$.

Pembiayaan dengan cara penyertaan secara langsung ini dilakukan dalam hal badan usaha perusahaan pasangan usaha sudah atau akan membentuk perseroan terbatas. Dengan demikian, dalam penyertaan secara langsung dalam bentuk saham ini dapat dilakukan dengan cara mendirikan suatu usaha bersama dalam bentuk perseroan terbatas, dan penyertaan/pengambilan sejumlah saham dalam simpanan (porto folio) pada perusahaan pasangan usaha. ${ }^{7}$

b. Penyertaan melalui pembelian obligasi konversi (quasi equity participation); dan/atau

Penyertaan secara tidak langsung adalah penyertaan modal oleh perusahaan modal ventura pada perusahaan pasangan usaha tidak dalam bentuk modal saham (equity), tetapi dalam bentuk obligasi konversi (convertible bond) atau partisipasi terbatas/bagi hasil (profit sharing). Kedua bentuk penyertaan secara tidak langsung ini sudah barang tentu dalam operasionalnya akan mempunyai konsekwensi yang berbeda

\footnotetext{
${ }^{6}$ Pasal 4 Peraturan Menteri Keuangan Nomor 18/PMK.010/2012 tentang Perusahaan ModalVentura

${ }^{7}$ Sunaryo,Hukum Lembaga Pembiayaan, Jakarta: sinar Grafika hlm 32
}

satu sama lainnya, begitu pula dengan bentuk-bentuk dari penyertaan secara langsung. ${ }^{8}$

Obligasi merupakan salah satu jenis surat berharga alternative yang dapat dipilih para insvestor untuk melakukan investasi. Para investor ini tertarik untuk membeli obligasi karena nilai bunga yang diberikan pada umumnya lebih tinggi dari bunga deposito.Atau jika bunga rendah, mungkin tertarik karena ada kelebihan lainnya, seperti dapat ditukarkan dengan saham (convertible) sehingga ada jenis obligasi yang disebut obligasi konversi (convertible bond $)^{9}$.

Obligasi konversi menutut Munir Fuady merupakan obligasi dimana pihak pemegang obligasi tersebut mempunyai hak atau kewajiban untuk menukarkan obligasi tersebut dengan saham dari perusahaan penerbit pada waktu yang ditentukan. Dalam kaitannya dengan modal ventura, penyertaan modal dalam bentuk obligasi konversi merupakan suatu pola pembiayaan perusahaan modal ventura pada perusahaan pasangan usaha yang awalnya dilakukan dalam bentuk utang piutang yang nantinya akan dikonversi menjadi saham.

\footnotetext{
${ }^{8}$ Sunaryo, hlm 33

${ }^{9} / \mathrm{bid}$
} 
c. Pembiayaan berdasarkan pembagian atas hasil usaha (profit/ revenue sharing)

Penyertaan modal ventura dalam bentuk partisipasi terbatas atau bagi hasil digunakan mana kala dari hasil pemeriksan awal yang dilakukan oleh perusahaan modal ventura terhadap perusahaan pasangan usaha, baik dari segi financial, manajemen maupun dari segi hukum dianggap tidak tepat jika dilakukan dengan cara penyertaan langsung atau obligasi konversi. Penyertaan dalam bentuk ini dapat dilakukan pada perusahaan pasangan usaha baik yang berbadan hukum maupun yang belum berbadan hukum, dengan catatan bilamana dilakukan pada perusahaan pasangan usaha yang belum berbadan hukum atau perseorangan maka yang bertanggung jawab adalah anggota atau perorangan yang bersangkutan secara pribadi ${ }^{10}$.

Perjanjian modal ventura merupakan perwujudan dari adanya kesepakatan antara modal ventura dan perusahaan pasangan usaha yang isinya memuat persyaratan tertentu. Secara umum, isi dari perjanjian modal ventura memuat ${ }^{11}$ :

a) Bentuk pembiayaan/penyertaan modal yang digunakan; b) Besarnya jumlah dan presentase penyertaan modal;

c) Jangka waktu penyertaan modal;

d) Penggunaan pembiayaan oleh perusahaan pasangan usaha;

e) Cara divestasi termasuk divestasi yang dipercepat;

f) Ketentuan put option, yaitu setelah jangka waktu tertentu perusahaan pasangan usaha diharuskan membeli kembali saham perusahaan modal ventura; dst

Dari penjelasan diatas maka dapat disimpulkan bahwa bentuk penyertaan (pola hubungan hukum mana yang dipilih) akan dimasukkan di klausul dalam perjanjian modal ventura.

Berdasarkan butir 5 ayat

Konfirmasi Pembiayaan ${ }^{12}$, yaitu:

Atas fasilitas pembiayaan tersebut , "Penerima Fasilitas Pembiayaan" wajib untuk membayar Bagi Hasil atas usaha atau sesuai dengan kesepakatan kepada "Sarana" dengan perhitungan sebagai berikut:

a) Bagian Bagi Hasil yang menjadi milik/hak "Sarana" adalah sebesar ......\% (.....persen) perbulan.

\footnotetext{
${ }^{10}$ Sunaryo, hlm 35

${ }^{11}$ lbid, hlm 28
}

12 Dokumen PT. Sarana Jateng Ventura 
b) Bagian Bagi Hasil yang menjadi milik/hak "Penerima Fasilitas Pembiayaan" sebesar ....\% (....persen) perbulan.

Dalam kerjasama modal ventura antara PT. Sarana Jateng Ventura dengan Pasangan Usahanya dari ketiga Pola Hubungan Hukum sebagaimana diatur dalam Peraturan Menteri Keuangan Nomor 18 /PMK.010/2012 yang lebih diminati adalah kerjasama dengan pola Bagi Hasil.

Menurut Budi Soepriyanto, SE, MM, Koordinator Investasi PT. Sarana Jateng Ventura, pemilihan penyertaan modal dengan pola bagi hasil banyak dipilih oleh perusahaan pasangan usaha dengan alasan ${ }^{13}$ :

a) Kebanyakan perusahaan pasangan usaha merupakan perusahaan keluarga, sehingga sulit menerima penyertaan modal dalam bentuk penyertaan saham atau penyertaan melalui obligasi konversi.

b) Jika perusahaan pasangan usaha telah bersedia menerima penyertaan modal, tetapi masih berkebertan apabila ada pihak lain yang ikut mengurusi manajemen perusahaan.

13 Hasil wawancara Annelia Rositasari dengan Budi Soepriyanto, SE, MM, Koordinator Investasi PT. Sarana Jateng Ventura pada tanggal 29 Desember 2010 (dalam Tesisnya Annelia Rositasari, Kedudukan PT. Sarana Jateng Ventura dalam Manajemen Perusahaan Pasangan Usaha di Kawasan Industri Candi Semarang, Semarang: Magister Kenaktariatan Undip, 2011, hlm 113-114)

\section{Perlindungan Hukum}

Kajian mengenai perlindungan hukum modal ventura dapat dilakukan dengan dua pendekatan analisis, yaitu pendekatan analisis mikro dan makro. Pendekatan analisis mikro pada modal ventura hanya mengkaji aspek hukum privatnya dalam hal ini adalah perjanjian modal ventura, Sementara pendekatan analisis makro pada modal ventura mencakup aspek hukum privatnya dan juga hukum publik yang mengatur tentang modal ventura.

\subsection{Perlindungan Hukum secara Privat}

Dalam perjanjian modal ventura memiliki akibat hukum yang mengikat masing-masing pihak yang saling mengikatkan diri dalam perjanjian tersebut. Dalam perjanjian modal ventura yang menjadi subjek hukum utama yaitu Perusahaan Modal Ventura dan Perusahaan Pasangan Usaha. Pada pendekatan secara mikro, perusahaan dalam ranah privat pada kajian hukum ekonomi dipandang sebagai salah satu subjek hukum dari para pelaku ekonomi. Subjek hukum yang dimaksud adalah:

1) Manusia

2) Badan Hukum

Kegiatan Modal Ventura yang dilakukan oleh PT. Sarana Jateng Ventura 
dari segi keberadaannya sebagai subyek hukum telah memberikan perlindungan hukum bagi Perusahaan Pasangan Usahannya, karena kedudukannya jelas sebagai Badan Hukum. Perlindungan Hukum bagi masing-masing subyek hukum dalam hal ini PT. Sarana Jateng Ventura dan Perusahaan Pasangan Usaha tertuang dalam kontrak perjanjian modal ventura.

Berdasarkan teori, di dalam suatu hukum kontrak terdapat 5 (lima) asas yang dikenal menurut ilmu hukum perdata. Kelima asas itu antara lain adalah: asas kebebasan berkontrak (freedom of contract), asas konsensualisme (concsesualism), asas kepastian hukum (pacta sunt servanda), asa itikad baik (goodfaith), asas kepribadian (personality).

Menurut Bruggink, asas-asas hukum sebagai meta-normen (norma-norma berada di luar, namun melandasi dan menjiwai) dari norma-norma hukum yang konkret muncul sebagai kaidah-kaidah perilaku ${ }^{14}$.

Sebagai suatu perbuatan hukum, modal ventura tentu harus diback up oleh sektor yuridis, agar dapat berlaku dalam lalu

\footnotetext{
${ }^{14}$ Herlien Budiono, Asas Keseimbangan bagi Hukum Perjanjian Indonesia (Hukum Perjanjian Berlandaskan Asas-Asas Wigati Indonesia, Bandung: PT. Citra Aditya Bakti, 2006, hlm 2-3
}

lintas pergaulan bisnis $^{15}$. Dalam hal ini Perjanjian adalah sumber utama hukum modal ventura dari segi perdata ${ }^{16}$.

Menurut Munir Fuady, dokumen pokok yang paling penting sebagai bukti adanya kerja sama dalam usaha modal ventura adalah perjanjian modal ventura (venture capital agreement/shareholder agreement). ${ }^{17}$

\subsection{Perlindungan Hukum secara Publik}

Pasal 1 ayat (3) Undang-Udang Dasar Negara Kesatuan Republik Indonesia Tahun 1945 menyebutkan, bahwa "Negara Indonesia Negara Hukum".Negara hukum dimaksud adalah Negara yang menegakan supermasi hukum untuk menegakkan kebenaran dan keadilan dan tidak ada kekuasaan yang tidak dipertanggungjawabkan ${ }^{18}$.

Menurut isinya hukum dapat dibagi menjadi hukum privat (hukum sipil) dan

\footnotetext{
15 Munir Fuadi, Hukum tentang Pembiayaan, Bandung: Penerbit PT. Citra Aditya Bakti, 2006, hal 113

${ }^{16}$ Abdulkadir Muhammad, Op Cit hal 194

17 Sunaryo, Hukum Lembaga Pembiayaan, Jakarta: sinar Grafika, hal 28

18 MPR RI, Panduan Pemasyarakatan UndangUndang Dasar Republik Indonesia Tahun 1945, Sekertaris Jendral MPR RI, Jakarta, 2010, hlm, 46 (http://adedidikirawan.wordpress.com/teori-negarahukum-rechtstaat/ diambil tanggal 13 Maret 2014 pukul 08:13)
} 
hukum publik (hukum Negara) ${ }^{19}$. Hukum privat adalah hukum yang mengatur hubungan antara orang yang satu dengan orang yang lain, dengan menitikberatkan pada kepentingan perorangan ${ }^{20}$. Hukum publik adalah hukum yang mengatur hubungan antara Negara dengan warganegaranya ${ }^{21}$. Hukum publik yang memberikan perlindungan hukum terhadap Kegiatan Modal Ventura, diantaranya adalah:

1) Undang-Undang Nomor 3 Tahun 1982 tentang Wajib Daftar Perusahaan

Daftar Perusahaan itu penting untuk Pemerintah guna melakukan pembinaan, pengarahan, pengawasan dan penciptaan iklim dunia usaha yang sehat karena Daftar Perusahaan mencatat bahan-bahan keterangan yang dibuat secara benar dari setiap kegiatan usaha sehingga dapat lebih menjamin perkembangan kepastian berusaha bagi dunia usaha ${ }^{22}$.

Perlindungan kepada perusahaanperusahaan yang menjalankan usahanya secara jujur dan terbuka merupakan salah

19 C.S.T. Kansil, Pengantar Ilmu Hukum, Jakarta: Balai Pustaka, 2002, hlm 46

${ }^{20}$ lbid

${ }^{21} \mathrm{lbid}$

${ }^{22}$ Konsideran Undang-Undang Nomor 3 Tahun 1982 tentang Wajib Daftar Perusahaan. satu tujuan utama dari Undang-Undang tentang Wajib Daftar Perusahaan ${ }^{23}$.

Undang-undang tentang Wajib

Daftar Perusahaan adalah sebagai upaya dalam mewujudkan pemberian perlindungan tersebut, serta juga pembinaan kepada dunia usaha perusahaan, khususnya golongan ekonomi lemah.Dalam penyusunannya diperhatikan pula kebiasaan-kebiasaan yang benar-benar hidup dalam masyarakat pada umumnya dan dunia usaha pada khususnya ${ }^{24}$.

2) Undang-Undang Nomor 21 Tahun 2011 tentang Otoritas Jasa Keuangan Filosofis lahirnya Undang-Undang Nomer 21 Tahun 2011 tentang Otoritas Jasa Keuangan untuk mewujudkan perekonomian nasional yang mampu tumbuh secara berkelanjutan dan stabil, diperlukan kegiatan di dalam sector jasa keuangan yang terselenggara secara teratur, adil, transparan, dan akuntabel, serta mampu mewujudkan system keuangan yang tumbuh secara berkelanjutan dan stabil, dan mampu melindungi kepentingan konsumen dan masyarakat ${ }^{25}$.

Dalam Pasal 6 UU No. 21 Tahun 2011 tentang OJK, OJK melaksanakan tugas

\footnotetext{
${ }^{23}$ Penjelasan Undang-Undang Nomor 3 Tahun 1982 tentang Wajib Daftar Perusahaan

${ }^{24}$ lbid

${ }^{25}$ Konsideran Undang-Undang Nomor 21 Tahun 2011 tentang Otoritas Jasa Keuangan
} 
pengaturan dan pengawasan terhadap Lembaga Pembiayaan, termasuk Perusahaan Modal Ventura.

3) Undang-Undang Nomor 17 Tahun 2012 tentang Perkoperasian

Koperasi adalah badan usaha yang berbentuk badan hukum, dalam kegiatan Modal Ventura koperasi dapat menjadi subjek hukum baik subjek hukum sebagai perusahaan modal ventura ataupun sebagai perusahaan pasangan usaha, seyogyanya telah ada perlindungan hukum untuk wujud adanya subjek hukum dalam Pembiayaan Modal Ventura.

4) Undang-Undang Nomor 20 Tahun 2008 tentang Usaha Mikro, Kecil, dan Menengah

Dibentuknya Undang-Undang tersebut adalah untuk memberdayakan Usaha Mikro, Kecil, dan Menengah untuk mendapatkan perlindungan.

5) Peraturan Menteri Keuangan Nomor 18/pmk.010/2012 tentang perusahaan Modal Ventura

Pada ditetapkannya Keputusan Menteri Keuangan No.1251/KMK.013/1988 tentang Ketentuan dan Tata Cara Pelaksanaan Lembaga Pembiayaan, UMKM belum medapat perlindungan hukum untuk dapat menerima pembiayaan Modal Ventura, Namun saat ini dengan ditetapkannya Peraturan Menteri Keuangan Nomor 18/PMK.010/2012 tentang Perusahaan Modal Ventura, Usaha Mikro, Kecil, dan Menengah telah mendapat perlindungan hukum untuk menjadi Perusahaan Pasangan Usaha dari Perusahaan Modal Ventura.

Menurut peneliti, Kegiatan Pembiayaan Modal Ventura yang dilakukan oleh PT. Sarana Jateng Ventura dengan Perusahaan Pasangan Usahanya mendapatkan perlindungan baik dari segi hukum privat maupun hukum publik. Di akhir pembahasan ini peneliti memberi penekanan bahwa ada dua bentuk perlindungan hukum yang melindungi subyek hukum pembiayaan modal ventura dalam hal ini adalah PT. Sarana Jateng Ventura yaitu Perlindungan Hukum Prefentif dan Perlindungan Hukum Represif. Wujud perlindungan preventif seperti perlindungan yang diberikan oleh UU No. 21 Tahun 2011 tentang OJK, OJK melaksanakan tugas pengawasan terhadap Lembaga Pembiayaan termasuk Perusahaan Modal Ventura.Perlindungan hukum represif adalah perlindungan akhir berupa tanggung jawab perusahaan, baik Perusahaan Modal Ventura maupun Perusahaan Pasangan Usaha. 


\section{KESIMPULAN}

1. Pola hubungan hukum penyaluran modal ventura yang terjadi antara PT. Sarana Jateng Ventura dengan Perusahaan Pasangan Usahanya, bila dipandang dari sudut klausul Perjanjian telah terkonstruksi sebagai perjanjian modal ventura sebagaimana diatur dalam Peraturan Menteri Keuangan Nomor 18/PMK.010/2012 tentang Perusahaan modal Ventura yaitu pola hubungan hukum dengan pola Bagi Hasil,

2. Perlindungan hukum terhadap PT. Sarana Jateng Ventura dan Perusahaan Pasangan Usaha selaku subyek hukum telah mendapat perlindungan baik dari segi hukum privat maupun hukum publik. Dari segi hukum privat perlindungan hukumnya adalah perjanjian modal ventura. Dari segi hukum publik perlindungan hukumnya adalah peraturan Per-Undang-Undangan. Ada dua bentuk perlindungan hukum yang melindungi pembiayaan modal ventura yaitu perlindungan hukum prefentif dan perlindungan hukum represif.

\section{DAFTAR PUSTAKA}

Annelia Rositasari, 2011, Tesis:Kedudukan PT. Sarana Jateng Ventura dalam Manajemen Perusahaan Pasangan Usaha di Kawasan Industri Candi Semarang, Semarang: Magister Kenaktariatan Undip

C.S.T. Kansil, 2002, Pengantar Ilmu Hukum, Jakarta: Balai Pustaka

Hasanuddin Rahman, 2003, Segi-segi Hukum \& Manajemen Modal Ventura, Bandung: PT. Citra Aditya Bakti

Herlien Budiono, 2006, Asas Keseimbangan bagi Hukum Perjanjian Indonesia (Hukum Perjanjian Berlandaskan Asas-Asas Wigati Indonesia, Bandung: PT. Citra Aditya Bakti

http://www.aspek hukum dalam bisnis.com

http://adedidikirawan.wordpress.com/teori-negarahukum-rechtstaat/

Munir Fuadi, 2006, Hukum tentang Pembiayaan, Bandung: Penerbit PT. Citra Aditya Bakti

Peraturan Menteri Keuangan Nomor 18/PMK.010/2012 tentang Perusahaan ModalVentura

Sunaryo, Hukum Lembaga Pembiayaan, Jakarta: sinar Grafika

Undang-Undang Nomor 3 Tahun 1982 tentang Wajib Daftar Perusahaan

Undang-Undang Nomor 20 Tahun 2008 tentang Usaha Mikro, Kecil, dan Menengah

Undang-Undang Nomor 21 Tahun 2011 tentang Otoritas Jasa Keuangan

Undang-Undang Nomor 17 Tahun 2012 tentang Perkoperasian 